Logos Universality Mentality Education Novelty, Section: LAW

ISSN: $2284-5968$ (print), ISSN: $2284-5968$

(electronic)

Covered in: CEEOL, Index Copernicus, Ideas

RePeC, EconPapers, Socionet

\title{
PRELIMINARY CHAMBER JUDGE IN THE NEW CODE OF CRIMINAL PROCEDURE
}

\author{
Dănuţ NEACŞU \\ Luminiţa SIMA \\ Logos Universality Mentality Education Novelty, Section: \\ LAW, 2014, Year III, Issue 1, pp: 31-38 \\ Published by: \\ Lumen Publishing House \\ On behalf of: \\ Lumen Research Center in Social and Humanistic Sciences
}




\title{
Preliminary Chamber Judge in the New Code of Criminal Procedure
}

\author{
Dănuț NEACŞU ${ }^{1}$ \\ Luminiţa SIMA ${ }^{2}$
}

\begin{abstract}
The provisions of the new Code of Criminal Procedure regarding the preliminary chamber judge (art. 345), contain a series of omissions (for instance, the Code does not provide the remedy solution in case of sanctioning the prosecution acts performed in violation of law), inconsistencies and gaps which may cause interpretation and enforcement difficulties in this kind of judicial proceedings. Accordingly, in the current article, the authors identify these situations and analyse them in the framework of current regulations in force, also suggesting possible solutions. Therefore, the main objective of this research consists in exploring the text of the New Code of Criminal Procedure governing the procedure of the preliminary chamber. In this context, several inconsistencies and gaps that will create difficulties of interpretation and application will be signalled. One of them refers to the text of Art. 344 para. (2) and (3) of the New Code of Criminal Procedure, which is incomplete in relation to the text of art. 54 with regards to the jurisdiction of the preliminary chamber judge and in relation to the text provided by art. 342 of the same Code, which legalises the object of the procedure in the preliminary chamber. In conclusion, the article proves of high interest due to its novelty and underlined inconsistencies.
\end{abstract}

\section{Keywords:}

Preliminary Chamber Judge, Functional Competence, Omissions, Inconsistencies, Prosecution Acts, Legality Control.

1 Lecturer, $\mathrm{PhD}$. at "Andrei Saguna" University of Constanta, Romania, danut.neacsu@yahoo.com.

2 Graduate student, Ovidius University, Constanta, Romania, luminita.sima38@yahoo.com. 


\section{Introduction}

Preliminary chamber judge has the right to check the lawfulness of the accusation completed by the prosecutor, to manage the evidence during the prosecution, and also to solve the complaints against the prosecutors' solutions for not sending someone for trial, as well as to take decisions with respect to the preventive measures. The term for the procedure within the preliminary chamber is utmost 30 days from the date of registering the case in court, but it cannot be shorter than 15 days from the same date. Preliminary chamber judge is limited with respect to attributions and decisions, and after analysing the law articles, quite a lot of doctrinaires have claimed that this judge cannot guarantee a real protection of the defendant's rights.

\section{Authority of the Preliminary Chamber Judge}

According to the stipulations in art. 54 from the Code of Criminal Procedure (Law no. 135/2010), the judge for the preliminary chamber, a new judicial body created to apply the principle of separating the judicial functions within the criminal trial, stipulated by art. 3 para. 1 letter c) has the functional authority:

- to check the lawfulness of managing the evidence and of performing the procedural acts by the criminal prosecution bodies;

- to solve the complaints against the solutions for not sending someone for trial or not prosecuting someone;

- to solve other situations expressly stipulated by law;

Within this context, for exercising this new judicial function, the Code of Criminal Procedure stipulated in Title II, the object and the procedure for the preliminary chamber, the measures and solutions which the preliminary chamber judge can order as well as the appeal which can be executed against the preliminary chamber judge's solutions, against the appeal to the preliminary chamber judge from the superior court or, as the case may be, the appeal to the authorized judicial panel, according to the law, from the High Court of Cassation and Justice.

Thus, the entire regulation was conceived with the aim to apply the new principle of separating the judicial functions, stipulated by art. 3 from the Code of Criminal Procedure, according to which, when exercising the trial function, the Court does not have any more the functional authority to check and to decide over the authority and the lawfulness of notifying the court, over the lawfulness of managing the evidence and over the lawfulness of performing the procedural acts by the criminal prosecution bodies. Obviously, the beneficial pursued aim was that of creating new guarantees regarding the lawfulness, the 
rigour and quality of evidence and of the procedures performed during the prosecution, as a non-public phase of the criminal trial, as well as regarding the act of notifying the court and, at the same time, to create conditions of a maximum impartiality and quality within the trial procedure for the judge who is performing only the trial function.

In this regard, according to the stipulations of art. 345 from the Code of Criminal Procedure, in exercising this new judicial function, the preliminary chamber judge checks and decides, within the council chamber, by means of a motivated conclusion, over the requests and the exceptions made by the prosecutor and by the parts, or made by him ex officio, having the following authorities:

- to ascertain irregularities of the notifying document;

- to sanction, according to art. 280-282 from the Code of Criminal Procedure, the prosecution procedures performed by infringing the law;

- to eliminate one or more evidences administered by infringing the law.

The conclusion drawn by the preliminary chamber judge which comprises the irregularities of the notifying document, the prosecution procedures sanctioned with an absolute or relative nullity and eliminated evidences, is communicated immediately to the prosecutor's office which completed the accusation according to art. 345 para. 2) from The Code of Criminal Procedure, which, according to art. 345 para. 3), within 5 days from the communication, must remedy the irregularities of the notifying document and must communicate to the preliminary chamber judge if he/ she maintains the disposition of sending for trial or requires the referral back of the cause for further investigation.

The preliminary chamber procedure is an autonomous judicial function within the criminal trial, which is differentiated from the other judicial functions. The preliminary chamber aims, simultaneously, to solve matters regarding the lawfulness of sending the defendant for trial and the lawfulness of administering the evidences, maintaining at the same time the prerequisites for solving the case at the court of first instance.

Within the preliminary chamber procedure, the defendant may formulate requests and raise exceptions referring virtually to the act of notifying the court, to the administered evidences, matters referring to the nullity of the criminal prosecution, the absolute or relative nullity alleged depending on the real case, and the preliminary chamber judge comes to check these exceptions and requests formulated by the defendant within this procedure before proceeding to the trial made by the court of first instance. This is because the act of notifying the court constitutes in fact the basis on which the defendant is going to be prosecuted during the trial. 


\section{Solutions which the Preliminary Chamber Judge can Offer - Gaps in Interpretation}

The solutions which the preliminary chamber judge adopts are stipulated by art. 345 from The Code of Criminal Procedure, in which, in our opinion it is incomplete, in relation to the quality standards aimed by the new regulation, because it does not stipulate the restorative measure which is imposed in the case that the preliminary chamber judge „sanctions, according to art. 280-282, the acts of criminal prosecution performed by means of infringing the law", with the assumption that he/ she ascertains infringements of the legal dispositions which stipulate the compulsoriness of the suspect's or the defendant's presence when their participation is obligatory under law or the infringement of the legal dispositions regarding the assistance of the suspect or the defendant by the lawyer, as well as the other parts when assistance is obligatory. Thus, these infringements generate the absolute nullity under the conditions stipulated by the art. 281 para. 1) letter e) and f) from the New Code of Criminal Procedure and by para. 4) in the same text.

Through this essential omission, the new regulation is below the standards of the regulation in the old Code of Criminal Procedure which, according to art. 332 para. 2) final thesis, stipulated the solution of withdrawing the case and referral back to the prosecutor for restoring the prosecution in case of infringing the stipulations regarding the presence of the charged individual or the defendant and their assistance performed by the defender.

This omission of the text in art. 346 from the Code of Criminal Procedure is necessary to be completed meaning that it should stipulate the solution to withdraw the case for restoring the criminal prosecution in the two cases of absolute nullity. Not accepting this completion would mean to accept the non-existence of a solution for such infringements which generate the sanction for absolute nullity regarding the criminal procedure performed under these illegal conditions, an infringement which imposes, obviously, the solution to restore the prosecution by respecting the law.

By exploring the texts from the new Code of Criminal Procedure which regulates the preliminary chamber procedure, there can be seen some mismatches and gaps which will generate interpretation and application difficulties.

Thus, one of these refers to the text in art. 344 para. 2) and 3) from the Code of Criminal Procedure, which is incomplete in relation to the text of the art. 54 which regulates the authority of the preliminary chamber judge and the one stipulated by art. 342 from the same Code, which regulates the object of the procedure in the preliminary chamber.

The arguments are the following: 
According to art. 54 The Code of Criminal Procedure, the preliminary chamber judge is the judge who, within the court, according to its authority:

checks the lawfulness of sending someone for trial as disposed by the prosecutor;

- checks the lawfulness of administering the evidences and of performing the procedural acts by the criminal prosecution bodies;

- solves the complaints against the solutions of not prosecuting or not sending someone for trial;

- solves other situations expressly stipulated by the law.

Art. 342 from the Code of Criminal Prosecution stipulates that the object of the preliminary chamber procedure is the checking, after sending for trial, of the authority and the lawfulness of notifying the court, as well as the checking of lawfulness for administering the evidences and performing the acts by the criminal prosecution bodies.

The text of art. 344 para. 2) and 3) from the Code of Criminal Procedure, regulating the preliminary measures which the preliminary chamber judge is obliged to take with the aim of fulfilling his task, at the same time with communicating to the defendant of the certified copy of the accusation, stipulates that he must inform the defendant about the object of the preliminary chamber procedure, the right to hire a defender - and when the judicial assistance is obligatory - to designate a defender ex officio - and the term which cannot be shorter than 20 days - during which he/ she „can formulate, in writing, requests and exceptions regarding the lawfulness of administering the evidences and of performing the acts by the criminal prosecution bodies".

Thus, from the way of drafting the para. 2) and 3) of the abovementioned text, as against the texts in art. 54 and art. 342 from the Code of Criminal Procedure, it can be easily ascertained, that within the contents of the two paragraphs in art. 344, the judge's obligation to communicate to the defendant's defender, chosen or ex officio, the possibility to formulate in writing, requests and exceptions referring to the ,authority and the lawfulness of notifying the court".

It is obvious that this major omission of the text in art. 344 para. 2) and 3) from the Code of Criminal Procedure is imposed to be completed by the law-maker, but until then, it can generate difficulties in applying in practice, meaning that it can be understood, in reality, that the defendant's defender cannot formulate requests and exceptions regarding the ,authority and the lawfulness of notifying the court" and, thus, that the preliminary chamber judge does not have the obligation to check and to decide upon the ,authority and lawfulness of notifying the court", but only upon the lawfulness of administering the evidences and of performing the acts of prosecution. 
Thus, in order to determine a correct interpretation and application of the text in art. 344 para. 2) and 3) from the Code of Criminal Procedure, it is imposed that the chosen or ex officio defender, upon receiving the written communication stipulated by art. 344 para. 2) and 3) from the Code of Criminal Procedure, should notify the preliminary chamber judge about the incomplete content of the communicated rights and to claim a new term of 20 days in order to formulate written requests and exceptions also regarding the infringements referring to the authority and the lawfulness of notifying the court.

At the same time, regarding the pending court cases in the first instance, in which upon the date of coming in force of the new Code of Criminal Procedure, the court checked and decided by means of a conclusion over the lawfulness of notifications based upon art. 300 from the previous Code of Criminal Procedure (Law no. 29 from the $12^{\text {th }}$ of November 1968), but it did not check and did not decide upon the lawfulness of administering the evidences and the lawfulness of performing the procedural acts by the criminal prosecution bodies according to art. 332 para. 2) from the previous Code of Criminal Procedure, there appear problems which do not have solutions within Law no. 255/ 2013 either (Law no. 255/ 2013), of implementing the new Code of Criminal Procedure and within the new Code of Criminal Procedure either.

A first problem is that the conclusion by which the court decided over the lawfulness of the notification act cannot be attacked, by appeal, at the same time with the verdict, because according to art. 7 from the Law no. 255/ 2013, the pending court cases in the first instance, in which the criminal investigation started before the new law came in force, remain under the authority of the same court, the trial taking place according to the new law which does not contain the solution stipulated by art. 332 para. 2) from the previous Code of Criminal Procedure, of referring the cause back for infringing the legal dispositions regarding the notifying of the court; the new law, that is the new Code of Criminal Procedure, stipulates expressly that against the modality of solving the requests and exceptions which can prevent the starting of the trial, including the exception of illegally notifying of the court, the appeal is a litigation to the preliminary chamber judge from the superior court, which would obviously be inadmissible, without the possibility to be exercised in such a situation, against a decision coming from court. Such being the case, in such situations, the conclusion of the first instance regarding the lawfulness of the notification act, remains a judge's decision against which there is no appeal, this being inadmissible and inconceivable, contrary to the stipulations of art. 2 from the Protocol no. 7/ 1984 in the European Convention (The European Convention adopted in Rome on $4^{\text {th }}$ of November 1950) and implicitly contrary 
to the Constitution. (The Romanian Constitution modified and completed by Law no. 429/ 2003)

Another problem, generated by the same regulation omission from Law no. $255 / 2013$, for the situation of the cases in which, at the date of coming in force of the new Code of Criminal Procedure, the criminal trial has started, is that referring to the lawfulness of the evidences and the lawfulness of the procedural acts performed by the criminal prosecution bodies, there is no other filter because the court does not have the authority to eliminate evidences or to ascertain nullities of some criminal prosecution documents, as this authority was only given to the preliminary chamber judge according to art. 54 and art. 349 from the new Code of Criminal Prosecution.

Thus, these illegalities and inequities could and can be avoided by adequate regulations in Chapter II from Law no. 255/2013 for implementing the new Code of Criminal Procedure, which should take into account the rules of implementation for the criminal procedure law in transitory situations and which imply the fact that ,the norms whose implementation stopped also after their coming out of force when they refer to authority, appeal and terms", there being a legal tradition and an interpretative one in this regard, according to which, by exception from the rule of immediate implementation of the criminal procedure law, in these 3 cases, the old criminal procedure law is to function again.

\section{Conclusions}

We consider that the debates which can arise regarding this institution are far from being exhausted. However, the novelty brought by the Code of Criminal Procedure can be appreciated, the one regarding the authority of the judge for the preliminary chamber, the preliminary chamber procedure respectively, by guaranteeing a specialized „filter” for notifying the court, by means of the dispositions' content which regulate this procedural phase and by means of the solutions which may be disposed.

In the same light, the problems generated by the introduction of the new institutions will surely lead to denouncing the inadvertencies or gaps by appeals for the law's sake.

\section{REFERENCES}

Law no. 135/2010 regarding the New Code of Criminal Procedure, published in The Official Monitor no. 486 from the $15^{\text {th }}$ of July 2010, in force from the $1^{\text {st }}$ of February 2014, update by: OUG no. 3/2014 - for taking some measures necessary for implementation of Law no. 135/2010 
regarding the Code of Criminal Procedure and for the implementation of other laws The Official Monitor 98/2014; Law no.255/2013 - for implementing Law no. 135/2010 regarding the Code of Criminal Procedure and for the modification and completion of some laws which comprise criminal procedure dispositions, The Official Monitor $515 / 2013$.

Law no. 29 from the $12^{\text {th }}$ of November 1968 from the Code of Criminal Procedure published in the Official Monitor no. 145/ $12^{\text {th }}$ of November 1968.

Law no. 255/ 2013 for the implementation of Law no. 135/ 2010 regarding the Code of Criminal Procedure and for the modification and completion of some laws which comprise criminal procedure dispositions, published in The Official Monitor no. 515 from the $14^{\text {th }}$ of August 2013.

Protocol no. 7, Strasbourg, the $22^{\text {nd }}$ of November 1984

The European Convention adopted in Rome on $4^{\text {th }}$ of November 1950. It entered into force on the $3^{\text {rd }}$ of September 1953. The Convention was amended by the Protocol no. 11, entered into force on the $1^{\text {st }}$ of November 1998. Romania confirmed the Convention and its additional Protocols by Law no 30 from the $18^{\text {th }}$ of May 1994, published in "The Official Monitor of Romania" no. 135 from the $31^{\text {st }}$ of May 1994, Protocol no 11 was confirmed by Law no. 79 from the $6^{\text {th }}$ of July 1995, published in "The Official Monitor of Romania", Part I, no. 147 from the $13^{\text {th }}$ of July 1995.

The Romanian Constitution modified and completed by Law no. 429/ 2003, published in The Romanian Official Monitor, Part I, no. 758 from the $29^{\text {th }}$ of October 2003, republished by the Legislative Council, under art. 152 from the Constitution, with updates of the naming and giving the texts another numbering (art. 152 became, under republished form, art. 156). 